\title{
THE SYNTHESIS OF PAINTING AND MUSIC: WASSILY KANDINSKY - ALFRED SCHNITTKE
}

\author{
Galina Zavadska \\ Daugavpils University Institute of Life Sciences and Technology, Latvia \\ Ilona Bagele \\ Daugavpils University, Latvia
}

\begin{abstract}
The interaction between colors and sounds, music and painting has existed long since. Throughout the centuries these two kinds of art have been developing simultaneously and in close contact with each other, besides. Composers, especially those of the $20^{\text {th }}$ century, find in the sphere of painting images for their musical compositions, without trying to depict definite plot lines or specific landscape sketches. The paper analyzes a specific composition by Alfred Schnittke - Wassily Kandinsky - The Yellow Sound. Research aim: to investigate the features of musical implementation of W. Kandinsky's ideas by Alfred Schnittke on the basis of a comparative analysis of specific compositions of both authors. Research method: a comparative analysis.
\end{abstract}

Keywords: synthesis of arts, analysis, composition techniques.

\section{Introduction}

The interaction between colors and sounds, music and painting has been existing long since, both in nature as well as in art. The Ancient Greeks already, and Aristotle among them, wrote that in terms of beauty and harmony colors correlate among themselves like musical consonances (Salder, 2012).

In Ancient India, there was a kind of painting based on musical themes vanika. This is a skill of illustrating a melody by using tools of painting. The musical-theoretical treaty Vish-nudharmotor (the $7^{\text {th }}$ c.) mentions a special kind of Indian painting on musical themes in which the seven sounds of the scale are correlated with seven colors (Babkina, 1966).

These two kinds of art develop simultaneously, being in a close contact with each other to no lesser extent than, for instance, music is with poetry. Musicians and music-making, musical instruments have been a favorite model for fine arts of different epochs. Therefore no wonder that color-sound sensations are characteristic of composers and painters, as well as art critics.

Fine arts constantly inspire composers to create musical compositions. Hungarian composer Franz Liszt admitted that Raphael and Michelangelo had helped him understand Mozart and Beethoven. German composer Robert 
Schuman considered that for a composer to study Raphael's pictures is as useful as for the painters to experience Mozart's symphonies. In the $19^{\text {th }}$ c., there appears a special genre - a symphonic picture. N. Rimsky-Korsakov marvelously depicts the sea (symphonic picture "Sadko"), A. Lyadov - the fairy-tale characters (“Baba-Yaga”, "Magic Lake”, "Kikimora”). M. Musorgsky has created a cycle on the pictures of painter and architect V. A. Hartmann "Pictures from the Exhibition".

And indeed, there are a lot of things that unite music and painting. The Russian composer of the $20^{\text {th }}$ c. Edison Denisov (1929-1996) considers that the parameters of the similarity between music and painting are as follows:

1) spatial laws (painting exists in a two-dimensional space, music - in one-dimensional);

2) arrangement of elements in space to create wholeness (a painter arranges the elements to be depicted in the picture, a composer arranges sounds on the spatial-temporal canvas);

3) each element has its own properties: any element that is to be portrayed has its own form and color, just like in music a sound has its own form (several parameters) and its own color (timbre);

4) elements interact among themselves (only in this way a painter and a composer create one whole);

5) likeness in the area of form (any work of art - be it artistic or musical - has its own form due to a definite logic of the distribution of elements in space);

6) the presence in the $20^{\text {th }}$ c. of a serial technique, both in music and painting; E. Denisov maintains that the serial principle of composition can be found in several pictures by P. Klee (Paul Klee 1879-1940) and those by P. Mondriaan (Pieter Cornelis (Piet) Mondriaan 1872-1944): Compositions of the period of 1917-1928 and Victory Boogie-Woogie (1944) by Mondriaan, Old Cords (1925) and A Blossoming Orchard (1930) by P. Klee (Denisov, 1986).

The $20^{\text {th }}$ c. was no exception, many composers continued this tradition. Russian and German composer Alfred Schnittke drew inspiration from the stage composition of Russian artist Wassily Kandinsky The Yellow Sound (der gelbe Klang) and created a composition of the same title in two variants: as a concert piece with a demonstration of the reproductions of artist's pictures and as a pantomime for a soprano, mixed choir in recording and an instrumental ensemble.

Research aim: to investigate the features of musical implementation of W. Kandinsky's ideas by Alfred Schnittke on the basis of a comparative analysis of specific compositions of both authors. 


\section{The Yellow Sound - History of Creation}

The stage composition The Yellow Sound by W. Kandinsky was published in the popular almanac The Blue Rider (1912). For Kandinsky, this is a synthetic work that combines color, plastic arts, speech, music (pantomime, colored projectors, orchestra, singers). W. Kandinsky's libretto has no plot, and thus it manifests abstractionism whose theoretician and forbearer he was. The publication in The Blue Rider provides also a detailed lighting score, instructions on the character of music and pantomime movements (Avtonomova, 2000).

The theoretical substantiation of the genre stage composition is given by Kandinsky in his book Concerning the Spiritual in Arts (Kandinsky, 2008). The idea about the synthesis of arts often emerges in this book, but the word is defined as the inner sound. The concept of yellow is also in the focus of the theoretical problems of this book. This color coupled with blue makes the first big contrast: yellow - implies warmth, orientation towards the viewer, movement outwardly (eccentric); blue - means cold, orientation away from the viewer, movement inwardly (concentric).

The Yellow Sound was to have become a demonstration of the principles of stage art formulated by W. Kandinsky, and not only on the pages of a journal, besides - in 1914, the composition was conceived to be performed in the Munich Art Theatre, however the plan which W. Kandinsky developed together with the musician Thomas De Hartmann (Thomas De Hartmann 1885-1956) and artists August Macke (August Macke 1887-1914), Franz Marc (Franz Marc 1880-1916) and Alfred Kubin (Alfred Leopold Isidor Kubin 1887-1959) was implemented neither then, nor later during the author's life (Tulyakov \& Bochkareva, 2009).

The emergence of A. Schnittke's idea about The Yellow Sound was related to the proposal of the Russian conductor Genady Rozhdestvensky (1931-2018) in 1974 to write a composition for the concert Music and Painting he was preparing then. G. Rozhdestvensky came up with the idea to choose as a theme something from works of painting, for instance, P. Klee, but A. Schnittke selected the scenario of The Yellow Sound. However, as V. Holopova and E. Chigareva note, due to some reasons the intended performance at Rozhdestvensky's concert did not occur (Holopova \& Chigareva, 1990). The work had its premiere only in 1975, France, at a small festival held in a remote place Saint-Maximin-la-Sainte-Baume. In Russia, The Yellow Sound with A. Schnittke's music was performed for the first time in P. I. Tchaikovsky Concert Hall on January 6, 1984. 
Zavadska \& Bagele, 2021. The Synthesis of Painting and Music: Wassily Kandinsky - Alfred Schnittke

\section{Composition The Yellow Sound by Wassily Kandinsky}

The Yellow Sound by W. Kandinsky is a stage composition consisting of the introduction and six "pictures". In the final variant of the title The Yellow Sound (the draft composition had the title The Yellow Flower) W. Kandinsky not only withdraws from objects, but also verbally characterizes the music material (sound) using tools of painting (colors). "Pictures" of the composition have no dialogues at all and consist basically of different scenographic solutions, producer's explications and remarks on actors' performance (Avtonomova, 2000, p. 109).

Esthetics of the theatre of symbolism, manifesting itself in allegory, estrangement of the drama world from reality, in focusing on human's inner, spiritual quest, is one of the basic sources of the conception of W. Kandinsky's theatric art (Podzemskaya, 2011).

Word sounds only in the introduction (like a choir singing behind the wings -8 verses) and in pictures two (recitation by people in unshapely costumes -6 verses), three (behind the wings some absolutely incomprehensible words are being shouted, for example, kalyazimunafakolya!) and four (a man orders a child - Keep silent!!) (Kandinsky, 2008, p.70).

In the few insertions of a sounding word, W. Kandinsky not only follows his own statements that a word should be used for creating a mood, but also gives a poetic interpretation of a contrast, which by his theory is as necessary in theatrical art. In his theory, W. Kandinsky rejects the sense of words, but in practice, he puts in them meaning important for understanding his conceptions.

According to D. Tuyakov and N. Bochkareva, in the form The Yellow Sound is published on the pages of The Blue Rider, it is a literary work. Paradoxically, but the synthetic composition turns out to be tightly linked with a word from the very beginning - although it is just a word, literature in a theatrical composition which in W. Kandinsky's opinion is of secondary importance compared to other arts (Tulyakov \& Bochkareva, 2009).

Color setting of the stage is not an indifferent background, but an active participant in the action. The narrative remarks reflect not only how important for the composition the color organization of the stage is, but also display the active, effective nature of the yellow color (See Fig. 1). The yellow color exists on the stage not merely as the color of something (giants' yellow faces in the first picture, a yellow flower on a green hill and yellow flowers in people's hands in the second picture, yellow giants in the fifth picture and a light-yellow giant in the sixth), but also as the color of a beam, as a concentrated manifestation of a yellow color as such. It relates, on the one hand, to the birth of a new being - a yellow color (Turchin, 2000), and on the other, to madness: Yellow is a typically earthly color. ...If compared with the state of a human soul, 
it could be used as a colored expression of madness, however not as melancholy, but as a fit of an utter madness, of a blind rage (Kandinsky, 2008).

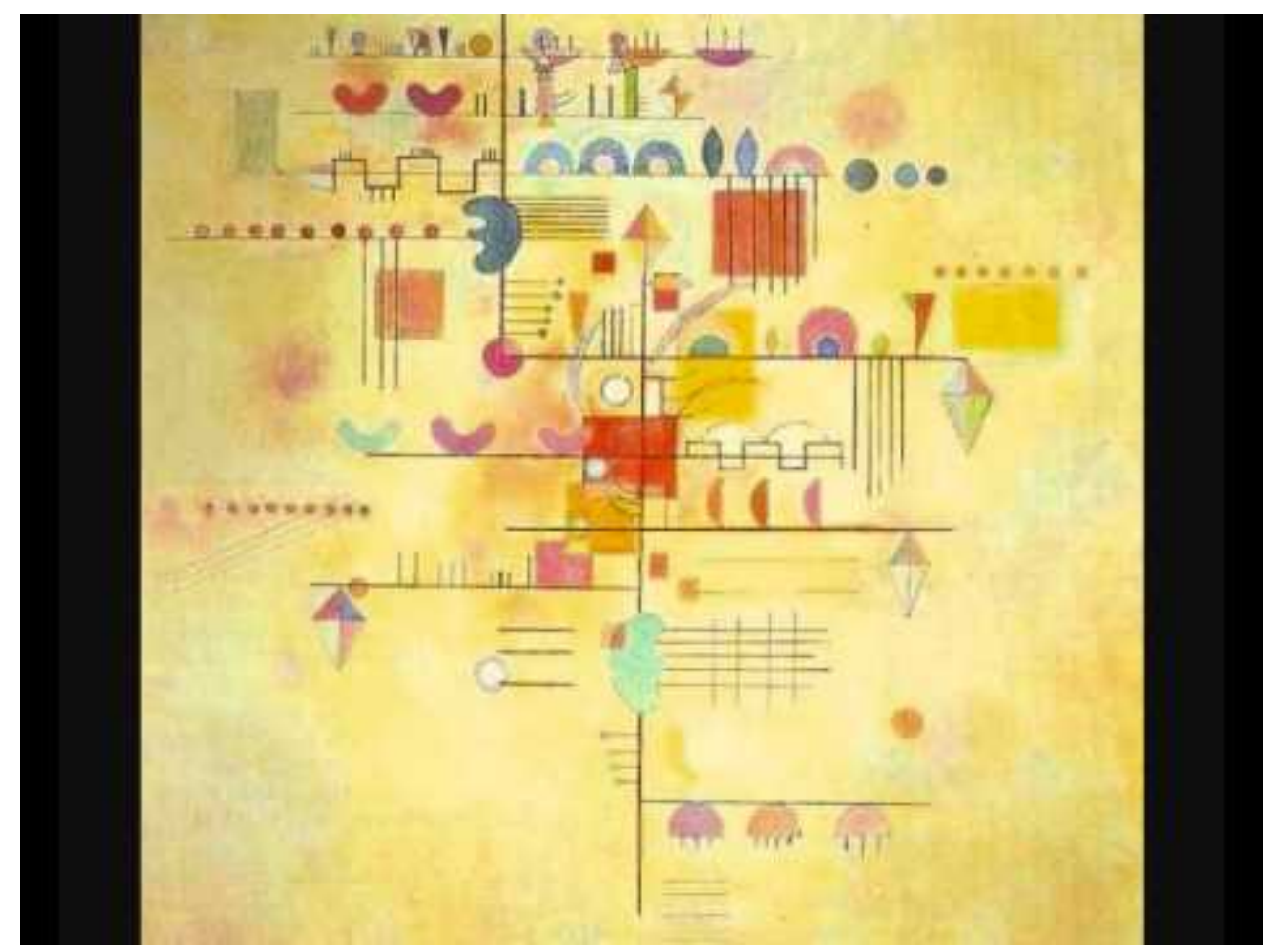

Figure 1 W. Kandinsky's The Yellow Sound

(https://www.google.lv/search?q=wassily+kandinsky+der+gelbe+klang\&tbm=isch\&source=i u\&ictx=1\&fir=QDkHeop20_UfwM\%253A\%252CuAoWwXtNoGd04M\%252C_\&usg=_M GVSHqe5inLxe9r2WxHdj2KquCw\%3D\&sa=X\&ved=0ahUKEwiPxImWw9XbAhXjJZoKH YiwA8AQ9QEIKDAA\#imgrc=uo4Yg3TTe0CsnM)

The description of music takes a special place in the text of The Yellow Sound. The publication in The Blue Rider gives a detailed lighting plot and instructions on the nature of music and pantomime movements. Moreover, in the alignment of components, W. Kandinsky did not strive for unison, like A. Skryabin in Prometheus, but rather for a counterpoint of music and color. For instance, when color is maximally intensive, music, on the contrary, abates (c \& Chigareva, 1990). The composition title itself shows the importance of the role of a sound. The specificity of The Yellow Sound lies in the fact that according to the author's conception, a real and not a metaphoric inner music must sound in it. In this composition, sound and visual events unfolding on the stage are inseparably linked. 
Zavadska \& Bagele, 2021. The Synthesis of Painting and Music: Wassily Kandinsky - Alfred Schnittke

\section{Musical Interpretation of W. Kandinsky's The Yellow Sound by Alfred Schnittke}

If A. Schnittke had exactly followed W. Kandinsky's conception, he would have produced an opera-pantomime. However, he confined himself to an instrumental ensemble and a lot of percussion instruments and the organ. Following W. Kandinsky's libretto, A. Schnittke created a double-purpose composition: to produce it on the stage and perform it at the concert with reproducing Kandinsky's pictures.

Its music retains the six pictures of W. Kandinsky's libretto, the characters' verbal text is used (very little) and the symbolic key sounds "a" and " $h$ " are specified. In the original, the verbal text is given in German, and A. Schnittke translated it into Russian for his composition.

By the nature of the musical material, A. Schnittke's composition develops concentrically from a distinct melodics in Part I to its gradual melting, transforming into aleatory and improvisatory in the center and then again to a gradual restoring of melodic patterns towards the end; it is enflamed by a sonoric-type introduction and conclusion (Holopova, 2008).

Schnittke has keenly perceived the specific energy of the composition. To decode its hidden meaning, an extremely modern language was chosen. On creating the musical text, the composer scrupulously studies the instructions given by the artist, and this is reflected in the score. A solo intended by W. Kandinsky for a tenor is replaced by a solo for a soprano by the composer. Speaking about The Yellow Sound the composer emphasizes: What concerns the colorfulness, here it is not only sonic, but also timbral (Shulgin, 2004). The choice of the performers also testifies to this fact: in addition to a soprano solo and a choir, there are key (the piano, harpsichord, organ), string (the violin, contrabass, electric guitar), wind (the clarinet, trumpet, trombone) instruments and a group of percussion instruments with bells, tam-tam, marimba and a vibrator. The solo part is given a special role by the composer. Without giving a specific text to a singer, he uses several vocal-speech techniques which allow using a high female voice as a special timbral color. The timbre of the voice is approximated to instrumental sounding and the voice becomes an equal member of the instrumental ensemble.

The idea of the composition is defined by a composer as a traditional conflict between Good and Evil, Light and Darkness. On the stage this is - a Heroine - an Eternal Light. A Male in White, a Yellow figure, who are opposed by a Black Man, and Giants. True, here the main thing for me was still the way itself to embodying this eternal dualism: I mean the relations between plasticity and light-color solutions, and revealing them in the static state and in the 
dynamic forms of sonoristic movement not approbated by me yet. (Shulgin, 2004).

The Yellow Sound is one of the most sonoristic works by A. Schnittke where the idea of interpreting a sound as a color is implemented on the level of contemporary possibilities in music. However even this music is not purely sonoristic, the composition is interwoven by a development of the melodic and rhythmic thematic aspect.

In his talk with D. Shulgin about the harmonic structure of The Yellow Sound score, the composer maintained that for him important seemed two ways: one - this is a color-light play resulting not as much from a formal calculation as shining from inside, from some audible imagery fragments of the libretto; the second - building up the plot canvas with definite, well-considered temporal spaces, characters colored by the light of their own tones. Both ways were to merge in the symbols of actions, phenomena, different entanglements of the libretto always perceived intuitively - at least it was conceived in this way. What concerns colorfulness, here it is not only sonic, but timbral to the same extent also.

In this connection, some sonoristic findings in the The Yellow Sound score can be mentioned: the unusual color at the beginning of the introduction whispering of the choir upon entering; in timbral aspect it blends with the whispering sound waves created by tam-tam beats. From mysterious sine-curvelike sounds of the choir, the common sounding passes over to trilling of the clarinet and then to a steady rhythmic beat of the cembalo and the piano. Speaking about the sonority of the choir sounding, the composer himself emphasizes that in Part II - it is a bewitching magic repetition of some sounds and short replicas; and spasmodic exhalations, different splashes, multi-layered pedaling - in Part III and Part V (Shulgin, 2004).

Among the original sonic-intonation moments the color of the piano can be mentioned: glissando on the bass string, which sounds like the zither.

Apart from sonoristic techniques, the composer uses also rhythmic series in Parts I, II, V and VI, in Part III there is a lot of instrumental aleatory. Improvisational nature predominates in the musical canvas of the composition.

Originating from the laws of the musical language typical of the compositional technique of the second half of the $20^{\text {th }}$ century, A. Schnittke's compositions have specific techniques that complicate their performance. These involve: the peculiarities of the structure of vocal and instrumental parts; new technical requirements for the performers; agogic methods; presence of the element of play. 
Zavadska \& Bagele, 2021. The Synthesis of Painting and Music: Wassily Kandinsky - Alfred Schnittke

\section{Conclusions}

- $\quad$ A. Schnittke retains the six pictures of W. Kandinsky's The Yellow Sound and chooses an extremely modern musical language to reveal the artist's conception.

- In the compositions of both authors the esoteric and mysterious aspects as if combine with the cosmic infantilism.

- $\quad$ Both authors exalt the simplest forms, both visual and sonic.

- The sonic-intonation improvisation of sound forms in A. Schnittke's works is subordinated to a strict compositional logic.

\section{References}

Avtonomova, N.. (2000). Scenicheskie kompozicii V.V.Kandinskogo. Russkij avangard 1910h-1920-h godov i teatr. St-Peterburg: Dmitrij Bulanin, 106-115.

Babkina, M. (1966). Muzyka Indii. Kul'tura sovremennoj Indii. Moscow: Nauka,172-80.

Denisov, E. (1986). Sovremennaja muzyka i problemy jevoljucii kompozitorskoj tehniki. Moscow: Sowetskij kompozitor.

Holopova, V. \& Chigareva, E. (1990). Al'fred Shnitke: Ocherk zhizni i tvorchestva. Moscow: Sowetskij kompozitor.

Kandinsky, W. (2008). Izbrannye trudy po teorii iskusstva: v 2 tomah. Tom 1. Moscow: Gileya.

Podzemskaya, N. (2011). «Zhivopisnyj kontrapunkt» V.V.Kandinskogo, ili ob abstraktnom v iskusstve. Moscow: Nauka, 113-157.

Salder, M.T.H. (2012). Concerning the Spiritual in Art (Dover Fine Art, History of Art). Canada: General Publishing Company.

Tulyakov, D. \& Bochkareva, N. (2009). Sootnoshenie verbal'nogo i vizual'nogo v manifestah russkogo kubofuturizma i britanskogo imazhizma 1913-14 gg. Perm, 329-333.

Turchin, V. (2000). Teatral'naja koncepcija V. V. Kandinskogo. St-Peterburg: Dmitrij Bulanin, 73-105.

Shulgin, D. (2004). Besedy s kompozitorom - 1976-1977 gg. Moscow: Izdatelskij Dom "Kompozitor". 